\title{
Strange Topography: Globalization at Ground Zero
}

\author{
Vincent Mosco' \\ Queen's University
}

\begin{abstract}
This article, which is based on the keynote presentation delivered at the 2006 Conference of the Canadian Communication Association in Toronto, discusses the interplay between globalization and cities, using as the main illustration the trajectory of the World Trade Center in Manhattan, from its planning in the early sixties until its rebuilding initiatives today. The myth of a positive globalization with all its contradictions, and the threats presented by post-industrial projects to the urban landscape are explored via critical analyses of Negroponte's "digital revolution", its connection to fundamentalist religion, as well as the politics and economics involving the development of Lower Manhattan after the Second World War.
\end{abstract}

Key Words: Globalization; urban landscape; inequality; post-industrial project, World Trade Center.

Resumo: Este artigo, baseado na palestra de abertura da Conferência da Associação Canadense de Comunicação, na cidade de Toronto, em 2006, discute a interação entre globalização e cidades, tendo como exemplo principal a trajetória do World Trade Center em Manhattan, desde o seu planejamento no início dos anos sessenta, até as suas tentativas de reconstrução nos dias de hoje. O mito de uma globalização positiva com todas as suas contradições, e os perigos apresentados por projetos pós-industriais para a paisagem urbana, são explorados por meio de análises críticas da "revolução digital" de Negroponte, sua conexão com religiões fundamentalistas, assim como as questões políticas e econômicas envolvendo o desenvolvimento do Baixo Manhattan após a Segunda Guerra Mundial.

Palavras-chave: Globalização; paisagem urbana; desigualdade; projeto pós-industrial, World Trade Center.

1 Vincent Mosco is the Canada Research Chair in Communication and Society at Queen's University. He is the author of numerous books and articles including The Digital Sublime: Myth, Power, and Cyberspace (MIT Press, 2004), which won the 2005 Olson Award for outstanding book in the field of rhetoric and cultural studies. He is also the author of Continental Order? Integrating North America for Cybercapitalism (edited with Dan Schiller and published by Rowman and Littlefield, 2001) and The Political Economy of Communication: Rethinking and Renewal (Sage, 1996), which has been translated into Chinese (two editions- Beijing and Taiwan), Spanish, and Korean. 
Thank you very much. It is a pleasure to be here today and to speak on the congress theme Cities: Festivals of Knowledge. The recent death of Jane Jacobs has led many of us to think even more than usual about cities. For she made it easier for us to imagine cities as places to live and not just to display $19^{\text {th }}$ century fortress architecture or the purifying glass and concrete boxes of the twentieth. Above all she lived her work as an activist: leading the charge against the lower Manhattan expressway in the fifties, an action that ended the singular drive to highway construction in American cities, defeated the legendary master builder Robert Moses, and, unbeknownst to this then young boy, saved the neighborhood I played stickball in. Would that she were more successful in her fight against New York's World Trade Centre. But more about that later. Permit me to dedicate this talk to her, and for modifying slightly the overall congress theme in a way that you will surely appreciate. For the purposes of this talk let's call it Cities: Festivals of Communication. My theme is the interplay of globalization and cities, specifically the strange topography that characterizes our world today, all of which is packed into the place we call today ground zero.

Let's start with one of globalization's first cautionary tales. Like some of you I am sure, two years ago I went to see what Stephen Spielberg would do for or to H.G. Wells' novel and George Pal's 1953 film War of the Worlds. Spielberg's remake is interesting as a post 9/11 period piece- the terrifying other and the send-up to evolution, but it is Wells' story that continues to fascinate. There are many reasons for this but one stands out for me. It is riven by ideological contradiction. At its core, it is a deeply conservative tale because it portrays the utter, indeed pathetic, helplessness, of the human race in the face of the grotesque but seemingly all-powerful conquerors from Mars. We are helpless and hopeless to resist their robots, lasers and poison gas. But Wells's story is also a liberal celebration of evolution which saves us from conquest, not because of anything we have done, but because evolution has protected us, and not the Martians, from the sea of bacteria in which we live. That, of course, is but one, admittedly interesting reading. There is another that reverses the polarity. In this, the liberal side of the story is the uprising of the colonized others, subjects of the British empire, who, at the peak of British imperial rule, manage to turn the tables and capture the homeland, sacking London in the process. 
This works until, and here is where conservatism returns, Britain wins the day because it is inoculated with the protection of generations of its dominant culture before which the invading hordes ultimately wither. Whatever the interpretation, as Wells likes to remind us, they are still watching and waiting, likely to return. Today, globalization arises from the messy legacy of Wells' conflict-ridden tale.

Let's now turn to two images from the current mythos of globalization, the first and most important one comes from a best selling book by New York Times columnist Thomas Friedman who pronounces in the title that The World is Flat. Now we all know that it is not. So why has practically everyone been buying this book? Of course we do not live in a physically flat world, but Friedman offers a powerful vision of a world whose geography has been virtually flattened by computer communication. For him, whether you are a software engineer in Seattle or Bangalore, a teacher in Shanghai or London, or a video game fan in Paris or Tokyo the world is increasingly flat, shrinking down to the virtual singularity of private enterprise, information technology and the market. It offers great opportunity- a truly global market for what we do, but it also means that the software engineer in Seattle now competes for her job with someone in Bangalore, Hong Kong, or Prague for that matter. For Friedman this is an unabashed triumph because globalization is turning the world's figurative curves, mountain peaks and ocean depths into one gleaming flat surface.

Friedman's image is not the only global vision to capture the imagination. If his represents the model image of the neo-liberal, then the picture of the globe as a shiny blue marble, brimming with life in the dark expanse of space, offers the progressive counterpart. It is the image of the environmental movement that challenges us to see the globe as one world, mother earth, home to all of us, and needing all of our care and attention because it is threatened by those who see the earth as little more than a resource to be plundered. In this view, the earth is not flat, but it is certainly one beautiful blue ball, out there for all of us to see and to cherish.

Both of these images embody myths because they tell a powerful story that contains a core of truth and because they offer a transcendent vision of the sublime that 
lifts us out of our everyday, banal lives and inspires with an awesome and, at times, terrifying vision. As I have described in The Digital Sublime, myths like these, particularly when coupled with visions of boundless communication technology, convince many, including our most clever experts, that we are entering a new age at the end of history, the end of geography and the end of politics. As the former director of MIT's famed Media Lab, Nicholas Negroponte put it with apocalyptic fervor and no irony in his voice, "the world of atoms is ending, we must learn to be digital." It even led one of his MIT colleagues, Ray Kurzweil, to proclaim the end of death as we have known it because soon we will be able to upload our mind, spirit and identity into a computer that is only a few turns of Moore's Law away.

But how can these visions remain popular in the face of a world whose contours appear to be far from flat, whose shine often appears dull and where history, geography and politics, not to mention death, appear all too painfully real? Would we not serve truth better to jettison Negroponte for H.G. Wells or even Matthew Arnold who closed his poem Dover Beach with the memorable lines: "Nor certitude, nor peace, nor help for pain; And we are here as on a darkling plain Swept with confused alarms of struggle and flight, Where ignorant armies clash by night". Yes, post-industrial myth-makers gloss over significant truths that tell us the world has a strange topography indeed and though its tendencies are discernible, yes, capitalism has emerged from the Cold War hegemonic, it moves in no single, necessary, or essential direction.

But these myths also persist because they contain a potent if dangerous truth: we have experienced a transformation brought about by the global spread of communication and information technologies which is bringing about a remarkable expansion in markets. One result is unprecedented growth in material wealth in some parts of the world and for some peoples.

But myths need more than this to survive and thrive. Belief in the flat world, the shiny blue marble, in the end of history, geography and politics, and even in the end of death, are constantly threatened by present day events that suggest a far more mundane world than supporters envision and by historical reminders that tell us we have been here 
before. And indeed the historical record is full of such promises that would accompany the telegraph, telephone, radio, and television, not to mention nuclear power that it was believed for years would bring us energy in such abundance that it would be too cheap to meter. What gives us the strength to resist present day banality and the lessons of history to accept the myths of our digital age? I suggest it is because globalization is not just a political force bringing about a degree of material transformation, not just because it is, as some would have it, part of the great transformation that Karl Polanyi so eloquently chronicled in his history of capitalism. We resist the evidence of our daily lives and give in to a vast collective amnesia about history, because the images that make up globalization provide a comforting, transcendent, indeed heavenly, vision that allows us to shed the troubles of everyday life and the accusing finger of history. Could it be that if religion is the opiate of the masses then globalization is the opiate of the privileged?

Indeed our own field of communication studies shares in this mythmaking exercise because we tend to see communication as inherently bringing people together, in English it shares a root with community. Communication feeds the myths of globalization providing it with connections, the ties that form what Manuel Castells, resisting at all costs the term capitalist, calls instead a "network society."

But myths have their costs and the myth of globalization, like the myth of communication, masks significant truths that we ignore at our peril. First and perhaps foremost, globalization has been accompanied by massive growth in inequalities, deepening divides between rich and poor nations, deepening divides between urban and rural people, deepening divides over access to basic resources, including the technologies of communication that propel our myths (consider that the entire continent of Africa has fewer internet connections than the island of Manhattan). Rather than a flat world, there are many Grand Canyons, many Three Gorges that separate people today.

Important as these great divides are today, proponents of globalization have an answer. They claim that over time globalization will fill these divides with the wealth generated by economic growth. In other words, if the world is not flat today, it will soon become at least flatter. But that misses an important point, one that is all too often missed 
even by the critics of globalization. Globalization is central to the forces that promote division and conflict in the world today. Specifically, I contend that nationalism, terrorism and religious fundamentalism, three alleged enemies of globalization, are intimately connected to globalization and make full use of the instruments of communication that propel it. As a result, intrinsic to globalization today are the forces that would divide the world.

Nationalism is often set apart from globalization because it represents the old order of modernity based on competing and often warring states that resisted the inexorable pull of global markets and global culture. Indeed nationalism remains a tool of the anti-globalization movement as national sovereignty is upheld against the challenges to national companies, national trade unions, national public broadcasters and national systems of social welfare. But nationalism has now become a critical force in the spread of globalization as countries use national identity and all of the emotional sentiments it conjures to better compete in the global marketplace. Consider China with its massive mobilization of nationalism in the service of winning in global competition for markets. In this respect, globalization does not undermine nationalism; rather it sharpens nationalism turning it into a tool to more effectively promote the interests of nations in global competition. There is nothing terribly new here. After all, in the name of nationalism, nineteenth century America refused to protect the legal copyrights of authors whose works were printed outside of the United States, much to the chagrin of world famous writers like Charles Dickens who railed against copyright piracy in the United States. Like China today, the United States was simply using nationalism to better position itself in the early days of globalization. Once it became a net exporter of intellectual property, the US joined the world of global copyright protection and now echoes Dickens in attacking IP pirates. But the US still claims the national right to go to war to protect its power in global competition for oil. As the geographer Neil Smith puts it, "nationalism infuses the arteries of a globalizing capitalism.”

If nationalism is typically set apart from globalization; then terrorism, embodied in organizations like Al-Qaeda is considered its absolute antithesis. What can be more distant from a flat world or a shiny blue marble than the image of Osama bin Laden's band of 
marauding terrorists? Wasn't 9/11, as Ulrich Beck called it, "globalization's Chernobyl?" And yet, what recent success the Al-Qaeda network has enjoyed is based on following principles honed by some of the strongest supporters of globalization. As the head of the Rand Corporation's Washington office put it, "Indeed, what bin Laden has done is to implement for al-Qaeda the same type of effective organizational framework or management approach adapted by many corporate executives throughout much of the industrialized world over the past decade. Just as large, multinational business conglomerates moved during the 1990s to more linear, flatter and networked structures, bin Laden did the same with al-Qaeda." Like many modern corporations, al-Qaeda is a network-based organization that eschews the centralization and rigid hierarchy of the old order in favor of an agile collection of cells and individuals who connect and disconnect as necessary. One analyst literally attributes its success to modeling itself after global networked corporations like the franchise king McDonald's. Using a far hipper example, another scholar sees Al-Qaeda as an open source network whose structure and purpose are constantly revised and improved just like the Linux operating system. Moreover, like most such organizations, Al-Qaeda makes use of the most advanced forms of communication essential in any global operation today. Web sites are critical. Indeed, several of the terrorists who drove planes into the World Trade Center booked their tickets on Travelocity.com.

Finally, globalization goes hand in hand with religious fundamentalism, one of the most significant developments in America today. That alone is an extraordinary fact to consider. The richest nation in the world, which has built a global empire based on the most rational economic strategies, now identities one-third of its citizens as born again Christians who believe in the literal interpretation of the Bible which, I may not need to remind you, teaches us that the universe was created in seven days and is no more than 4000 years old. One of the principle reasons for the power of religious fundamentalism is the development of global networks that make use of advanced computer communication technologies to distribute their messages. The Christian Broadcasting Network is now the envy of public and private broadcasters worldwide. Consider this, churches that virulently oppose modern science, including the theory of evolution, which saved our bacon in Wells' 
War of the Worlds, use the most advanced technologies to spread their archaic messages to audiences around the world. Now that's globalization- a conflict-ridden contradictory process that does not stand above or against the ancient forces of nationalism, tribalism and religious fundamentalism. It advances them and they use it. Or to put it another way, yes, Marx (and Marshall Berman) were right: all that is solid does melt into air; but Marx was also wrong because what melts solidifies again into strange hybrid forms, remixes of nationalism, tribalism, religious fundamentalism and the globe-spanning networks that accelerate the process.

Globalization may be working successfully as myth, but is arguably failing as a political force. Study after study demonstrates that most trade, including the dreaded outsourcing, takes place within regions- North America, the EU, etc. (One prominent business professor is succinct: "globalization is a myth; instead world business is conducted on an intra-regional basis"). Moreover, to the extent that it is taking place, globalization moves goods not people. Only three percent of the world's people are immigrants compared to ten percent less than a century ago. Most attempts to create genuine global trade agreements have failed and the entire process is led by a nation trapped by massive economic debt and by the ideological debt it owes to nationalism and religious fundamentalism. Critics of globalization fear the shift of low wage work to India but fail to recognize that Indian firms are buying up information sector companies in the U.S., setting up branches across Canada, and leveraging great power in, of all places, China. Just as importantly, even if through some magic, the mythic visions of globalization were to materialize, they would fail catastrophically because they would almost certainly introduce massive changes in climate that would demonstrably alter life on earth. Yes capitalism is hegemonic, but globalization has no necessary direction, no teleology, it is constantly restructuring relationships in the world, constantly shuffling the deck. Rather than a flat world or a shiny marble, it presents a strange topography indeed.

And perhaps the strangest of all is the site of the former World Trade Center in Manhattan, once the icon of post-industrialism, then an anchor for Silicon Alley, and now simply ground zero. I turn to this place not just because I know it as the neighborhood of my childhood, but because more than any other it embodies the antimonies of 
globalization; inhaling, like some galaxy sucking black hole, all the failed aspirations for empire that marked the end of the last century, and the less than hopeful beginning of this one. Yes, New York is a festival of knowledge and of communication, but what it knows and what it communicates does not leave room for the buoyant optimism that more often than not accompanies those terms.

At the end of World War II the United States was poised to replace Great Britain as the dominant power in the world. In addition to its military power, the U.S. was armed with the potent new ideology of post-industrialism which served as an important departure from the traditional vision of a Fordist society built on manufacturing. Combining a near religious faith in communication and information technology with a similar belief in the inevitable triumph over poverty and working class life, the U.S. pressed forward with a vision of an epochal shift from factory to office, from reliance on manufacturing to services, and from power based on control over money to power rooted in the effective use of information.

Post-industrialism is not just a theory; it is also a prophetic vision that would be used to justify a battle at home against the American working class. In fact, even before Daniel Bell honed post-industrialism into a conceptual tool, it was used by leaders in business and government to justify profound transformations in American life. Specifically, it was a key intellectual and policy tool to eliminate proposals to modernize the manufacturing sector in major cities and it also legitimized massive urban redevelopment plans that would push the working class out of coveted urban areas and replace them with businesses catering to white collar employment and expensive housing for the new postindustrial elites. The Rockefeller family was in the forefront of pursuing post-industrialism "on the ground" and especially in reconstructing New York City as the capital of postindustrialism. Perhaps most fatefully the Rockefellers, more than anyone else, built its dominant architectural icon, the World Trade Center. They and their associates led a white collar army in what amounted to the Battle of New York City.

The first skirmish in this battle took place in the early 1950s at the northern end of Manhattan island, a distance from the primary campaign that would be fought over ground 
zero some years later. But lessons learned from the fight over Morningside Heights would serve the warriors who would build a World Trade Center, transform Lower Manhattan, and, ultimately much of the global political economy. The Heights contained Columbia University and several other of what the Rockefellers called "the institutions" precious to New York intellectual and cultural life and vital for the creation of a post-industrial society. The family, which was led by banker David and politician Nelson, supported the schools, cultural centers, and churches in the Heights. It was personally committed to what was dubbed this "Acropolis of America."

At the end of World War II, more than their financial support would be required as a new threat appeared at Morningside Heights. Here is how a memo to David Rockefeller described it. Titled "The Present Crisis," the memo is clinical in its description: "the white population decreased 12 percent, while the non-white population increased 71 percent... Again, let me repeat, if these minority groups come into the Heights in the usual way, it will benefit them little, if any, for the usual course of events will bring with it the same disastrous change in conditions which have resulted elsewhere; but the effects on the institutions will be catastrophic. All of these have appealed to me as reasons why the institutions and the City should combine to take steps necessary to guide local change along constructive lines." In essence as one commentator noted, it was necessary "to create a barricade, conveniently shielding the Acropolis of America from Harlem."

Fearing an influx of mainly working-class Hispanics and African-Americans, the Rockefeller team responded by leveling ten acres of working-class housing, replacing them with a cordon sanitaire of luxury housing that would ring "the institutions" of Morningside Heights protecting them from the "catastrophic" consequences of having to share the community with the working class. The latter fought back to prevent their removal in a community-wide Save Our Homes campaign organized in 1951, but to no avail. Community groups were labeled "communist-backed" in the press, making them enemies in the global fight against the terrorist Red Menace. This first major skirmish in the Battle of New York City ended as President Milicent McIntosh of Barnard College, one of the Height's premier institutions, accepted a one million dollar contribution from the Rockefellers and then literally took a crow bar and slammed it into one of the tenements 
scheduled for demolition, in a symbolic act of purifying a neighborhood of its working class. Armed with the ideology of post-industrialism, the Rockefellers and their coalition of developers, financiers, and planners, including the legendary Robert Moses, took the lessons learned from Morningside Heights and applied them again, only more spectacularly, in Lower Manhattan to build the capital of post-industrialism and the financial center of globalization.

Rockefeller family wealth shifted in the twentieth century from the oil that built the family fortune to banking and the finance capital that would build the bridge to a postindustrial future. The center of its financial power was the Chase Manhattan bank whose headquarters in Lower Manhattan stood alone amidst the structures representing the "old" economy. The bank's modern lines made visible the deep differences between the vision of Chase people and those working at the aging buildings of Wall Street, which provided the financial foundation for the manufacturing age. Unlike mid-town Manhattan which was home to the headquarters of media giants, pop culture palaces and other new economy institutions, including the family's own Rockefeller Center with its Radio City Music Hall and the studios of NBC, Chase alone in Lower Manhattan embodied the shift to a postindustrial society. The family, led by David as arguably the leading power broker in New York business and political circles, planned to change all that by turning Lower Manhattan into the center of global finance, trade and communication.

To assist, Chase Manhattan named a leader in the foreign policy establishment as its CEO. John J. McLoy was instrumental in the decision to drop the atomic bomb on Japan and became the first head of the World Bank. David Rockefeller was the bank's chief planner, but construction of the new capital of Friedman's flat world needed a top foreign policy adviser. Later, as governor of New York, Nelson Rockefeller would fine tune the precedent by appointing Henry Kissinger as his adviser for international affairs.

Such powerful figures were necessary because there was powerful opposition in Lower Manhattan. The district was also home to more than just the icons of Wall Street. The immediate area was called Radio Row, an agglomeration of electronics businesses that had occupied the area for forty years and employed about 30,000 people. It did not have 
the look of a post-industrial district but was successful in the electronics trade, providing one of the numerous craft-based industrial districts that made New York the model for what has become a fashion among urban planning scholars and policy makers- a set of overlapping specialized manufacturing districts that produce economies based on networks of business and family ties. Indeed in one of the supreme ironies of post-industrialism, a leading historians of New York City has speculated that had it not been wiped out by the World Trade Center, Radio Row might have provided the city with the foundation to develop what would eventually become Silicon Valley. After all, New York gave birth to the telecommunications and broadcasting industries and provided the headquarters for AT\&T and RCA.

Numerous attempts were made to build on this manufacturing infrastructure but most were ignored. These offered genuine visions of an alternative to the post-industrial future, and would be taken up by regions such as the Third Italy which recognized the value of maintaining a mix of manufacturing and service work

Business and community organizations in the surrounding area fiercely opposed the World Trade Center project and made use of tactics that today's anti-globalization protestors would recognize. One 1962 protest featured business leader Oscar Nadel lying in a coffin alongside a mannequin dressed up as Mr. Small Businessman and parading in a mock funeral procession to protest the imminent death of Radio Row. They were joined by activist intellectuals including Jane Jacobs. Alongside these opponents stood some of the city's more powerful real estate interests who feared that the WTC would significantly depress the market throughout the city. These were led by the owner of the Empire State Building who took out advertisements in New York's newspapers describing with eerie prescience and a now remarkable image, the likelihood that an aircraft would strike the proposed towers and bring them down.

To combat the opposition, proponents used many of the same tactics in use today, starting with the selective use of intelligence. In order to convince people that tearing down Radio Row and replacing it with the twin towers made economic sense, proponents commissioned a study from McKinsey and Company. But the study found that business 
had little need for a central structure to house foreign divisions because all business was becoming international and dispersing globally. Consequently, the plan would likely result in financial disaster with serious occupancy problems and little interest in the services that such a Center might provide. Instead of taking the McKinsey findings seriously, however, the Rockefeller led group refused to publish the report and forced the company to produce a different conclusion- after one WTC supporter took aside a McKinsey researcher and, in his words, "we stuck a steel rod up his fanny." Furthermore, just to be sure, supporters commissioned a new company to produce the results they wanted.

Trade center proponents also made use of supra-legal and even downright illegal institutions to win the day. The former was exemplified in the Port Authority of New York and New Jersey, one of the early public-private hybrids that enjoyed the power of a government agency (especially to expropriate land) without the need to answer to voters. The Port Authority was supposed to maintain the ports, bridges and tunnels that made up the New York and New Jersey transportation infrastructure. A product of modernist urban planning, it was also supposed to be insulated from daily political pressures, which would better enable it to operate efficiently. Instead, the agency was used to control the construction of a trade center that aimed to supercede physical transportation networks with the electronic networks of the digital age. In fact, the leadership of the Authority was keen to invest in the WTC partly because it had accumulated a massive surplus from its network of highway tolls and did not want to get involved in the politically messy business of providing public mass transit. Moreover, the Authority's unique status meant that the WTC project did not have to meet standard environmental and safety reviews which also sped the approval process. But it also created problems down the road because design features meant to maximize office space and less than rigorous fire protection measures also sped the collapse of the towers.

Trade center proponents also made use of extra-legal forces, in this case, the mafia, ultimately employing mob-controlled construction companies to manage local unions and skim money from contracts that were earmarked for such essentials as fire-proofing, the quality of which was questioned throughout the construction of the buildings. It would become a key flaw that hastened the collapse of the buildings. But the head of the 
company responsible for fire-proofing the buildings was not around to face the music because he was found murdered in the parking lot of one of the towers, the apparent victim of a rival mob family, led by the infamous John Gotti.

Empires have historically also used compradors or loyal local agents to carry out orders. This is no different when building a post-industrial empire at home. In the case of WTC, the architect Minoru Yamasaki served this role well, particularly since most leading architects were not interested in the project. The capital of post-industrialism required nothing short of the largest buildings in the world. Furthermore, developers wanted to maximize return on the dollar and so aimed to squeeze twelve million square feet of office space into the structures. Top architects would have nothing to do with the project because the only way to maximize rentable space would be to build two extremely tall boxes requiring radical and untested building techniques. Yamasaki was a middling architect whose only large project had resulted in complete disaster. That was the Pruitt-Igoe low income housing project in St. Louis which is still held up worldwide as a model of how to destroy a community through public housing. One urban historian has called it "arguably the most infamous public housing project ever built in the United States." In 1956, the development crammed 33 eleven story structures on a small site and it all was unceremoniously blown up in a 1972 demolition project that signaled the end of prisonlike public housing in the United States. Pruitt-Igoe was hardly the kind of track record that would recommend an architect for one of the most significant commercial real estate developments in history. But Yamasaki was pliable and so eager to please his superiors that he surprised even members of his own firm with his willingness to give up practically all of his remaining design principles to meet the demands to maximize rental space.

The fight over Ground Zero went on into the late 1960s and was not resolved until proponents offered the skeptical City of New York a sweetened deal. The Port Authority would literally extend Manhattan island with dirt dug out of the ground to build the towers and then assist in the creation of a luxury housing development to be called Battery Park City. The towers would not only be built, they would be coupled to a brand new upscale community to help replace the area's working class. The prospect of gentrifying the area by creating housing that the towers' white collar work force might 
occupy was enough to convince the city to accept the deal. To attract residents, a state-ofthe-art park was built on the Battery Park waterfront, at a time when most of New York's parks were suffering from neglect, and one of the city's premier public high schools, reserved for the city's best students, was moved into the area and placed in a brand new building costing $\$ 300$ million, at a time when New York's public schools were also suffering from years of dereliction.

Some would see the WTC as the product of power politics. But it was always encased in a supportive mythology as well, namely, purify the perceived blight of Lower Manhattan and, specifically, Radio Row with the magic dust of post-industrialism. For the architect Minoru Yamasaki, it was simple and downright Manichean. On the one hand was his design of the Towers evoking in his mind "the transcendental aspirations of a medieval cathedral." On the other was Radio Row, dismissed as "quite a blighted section." With thoughts of translucent towers filled with people running the digital world, he concluded: "There was not a single building worth saving."

There is something here reminiscent of Margaret Wertheim's discussion of the dual spaces of the medieval era, as cathedrals were built to purify the real but flawed space of daily life by making room for a spiritual space that would cleanse the blight of the banal, quotidian with a transcendent, indeed sublime, structure. But there is a difference. The medieval cathedral could cleanse and purify the soul but it acknowledged a world, however corrupt and sinful, outside its doors. Supporters of the post-industrial myth were not interested in sharing space. Post-industrial business would purify Fordism by eliminating its need to exist in the major cities of the world's richest nations. Post-industrial design would do the same by purifying, i.e., destroying, the spaces that got in its way. Now, not everyone agreed. Critics lambasted the towers as "graceless," a "fearful instrument of urbicide," and, as for the bit of ornamentation at the base which seemed to copy the uptown tower owned by a leading automobile manufacturer, it was viewed as "General Motors Gothic." The running joke was that the towers were actually recycled shipping boxes for the Chrysler and Empire State Buildings. Even today, architecture critics continue to assail the structures with one referring to their design as "one of the more conspicuous architectural mistakes of the twentieth century." 
As it turned out, the original fears of McKinsey and Company were correct and there were so few international businesses wishing to join the post-industrial society at the towers that Governor Rockefeller had to move in state government agencies and convince other levels of government to do likewise. Eventually anyone could rent space at highly subsidized rents. And in the 1990s, the towers and adjacent Battery Park City received the most real estate tax relief of any area in New York City.

Things got better as Lower Manhattan benefited from the dot-com boom and a high tech district known as Silicon Alley emerged in the late 1990s. New internet companies filled office buildings left vacant by financial services firms that relocated and replaced workers with new technologies. But by 2001, Silicon Alley practically vaporized in the dot-com bust leaving the new media industry in New York to the familiar conglomerates like AOL-Time Warner and IBM which could withstand the bust better than any of the many small firms that gave the city its hip attitude in the 1990s. With the digital hustlers on the run and the economy declining in the first nine months of 2001, the office glut returned and visionaries now turned to biotechnology to provide the next boost to the city economy, repeating a story spreading in cities whose dot-com hopes were turning into vaporware. On the day before the towers fell, there was 8.9 million square feet of vacant office space available in Lower Manhattan alone. The goal of turning Lower Manhattan into an office monoculture was failing even before two jetliners struck the twin towers

But empires are nothing if not persistent and the current plan is to rebuild the same amount of office space even though most agree that it will be even more difficult now that it means convincing people to come to work at ground zero. The centerpiece is a new building almost about as tall as one of the fallen ones but capped by a 400 foot illuminated tower that will raise the overall height of the building to reach the symbolically significant height of 1776 feet. Writing in The New York Times, Nicolai Ouroussoff captures the imperial foreboding embodied in the new design: "it is, sadly, fascinating in the way that Albert Speer's architectural nightmares were fascinating - as expressions of the values of a particular time and era. The Freedom Tower embodies, in its way, a world shaped by fear." 
As if to act out the fear embodied in the new design, about the same time the new building plans were being unveiled, the authorities overseeing the site engaged in an act of preemptive censorship. Responding to pressures to incorporate culture at the site, they planned to include two museums, a large International Freedom Center and a smaller Drawing Center, to display works of art. But these came under attack after a local newspaper raised fears that they would question America's past including its treatment of native and African Americans. The newspaper also revealed that the Drawing Center, now housed in SoHo, had displayed art linking President Bush to Osama Bin Laden and portrayed terror suspects as victims of American torture. Comparing the site to the beaches of Normandy and the attack on Pearl Harbor, the Governor of New York proclaimed: "We will not tolerate anything on that site that denigrates America, denigrates New York or freedom or denigrates the sacrifice and courage that the heroes showed on Sept. 11." Shortly thereafter, both museum plans were killed. Ground zero would be little more than business as usual and a memorial to the dead, with little thought to asking: why did they die?

Rather, the plan, long delayed by the banal battles over who gets to control the space, is to repurify the site with trees, grass and pools of water, the "easy listening music" version of a memorial. Just as the steel from the fallen towers was shipped overseas for recyling soon after the attack, practically all of the plans for the original site have been recycled in the new one. Office towers with the same amount of rentable space in a city that does not need it. A Freedom Tower that many fear invites a new attack (One planning expert calls it "a disastrous idea that should be scratched.") A government that commits to moving its workers into the buildings to avoid the appearance of failure. (For one analyst, this admits failure before a day has been spent on construction: "The need to relocate government offices to the World Trade Center in the 1970s was a sign of the economic failure of that project.") And now a memorial whose billion dollar price tag has shocked planners who see no chance of raising the money to create a structure that practically no one likes. (As the Times put it in an editorial: "The only thing a $\$ 1$ billion memorial would memorialize is a complete collapse of political and private leadership in Lower Manhattan.”). A genuine memorial would including rethinking the site and its 
adjoining neighborhoods. It would include revisiting Jane Jacobs' call for diversifying the local economy and its social class composition. Or even, as one historian has suggested, a combination of Jacobs' philosophy with a dose of her nemesis Robert Moses. For all of his near obsession with megaprojects that undermined local neighborhoods, Moses had a keen sense of how public investment in the transportation infrastructure and in recreation facilities spread the benefits widely. That he and others were able to accomplish so much of this during the Great Depression is also a model for how government can rebuild on a massive scale even when the national economy is severely eroded.

But none of this is likely to happen because ground zero embodies all of the pressures that have made globalization's promise of a flat world or a shiny blue marble so transparently mythic and unreachable. Fear now infuses all politics- global and local. The drive for profit, nationalism, terrorism and fundamentalisms of all sorts threaten to generate the moral and cultural equivalent of climate change. Our job, it seems to me, is not just to report on the weather. After all, it was one of my generation's poet troubadours who wisely pronounced that "you don't need the weather man (we might add, the weather channel) to know which way the wind blows." More than ever we need to be models of resistance, creators of alternatives, persistent challengers of the view that we have little choice but to serve power. Jane Jacobs would have it no other way. Neither should we. 